\title{
STUDY OF USE OF DISCONTINUOUS GLASS FIBERS IN PSC SPUN
}

\section{POLE}

\author{
M.B.Varma ${ }^{1}$, S.T.Patil ${ }^{2}$ \\ ${ }^{1}$ Associate Professor, Department of Applied Mechanics, Government College of Engineering Aurangabad \\ .Maharashtra, India \\ ${ }^{2}$ Assistant Professor, Civil engineering Department, Marathwada Institute of Technology, Aurangabad. Maharashtra, \\ India
}

\section{Synopsis}

The experimental study was carried out on the prestressed concrete spun pole. The length prestressed concrete spun pole was 13 meters. Prestressed concrete spun pole was cast at factory with use discontinuous glass fibers in high strength concrete. Glass fibers used were anticrack. Prestressed concrete spun pole without glass fibers was also cast at factory. Dimensions of the pole were outer diameter at top $206 \mathrm{~mm}$ and bottom $379 \mathrm{~mm}$. The thickness of pole kept 50 55mm. The investigations were done for spun poles for deflection parameter for different loads at factory. The investigations were also done to study final recovery of the deflection after removal of the load. The horizontal load is applied and increased in specific fraction up to design load and corresponding deflections of the pole were measured. The pattern of surface cracks on the pipe was also observed for comparisons. Final recovery of the deflection is noted for different load; load applied and load removal condition. All above parameters (deflection, crack pattern, recovery) were observed. Considerable improvement in the properties of PSC spun poles such as deflection, recovery after removal of load, increase in the load carrying capacity were observed during practical investigations.

Key words: PSC, GFRC, Deflection, cracks, Recovery

\section{INTRODUCTION}

Weaknesses of concrete are taken care of by adding appropriate $\%$ of reinforcement in the concrete. From last two decades a technique of Prestressed Concrete was introduced and is being used widely as it has many advantages over conventional R.C.C.

Considering the weaknesses of concrete and importance of concrete in the construction industry, it was started using glass fibers in the concrete to improve the various parameters of the concrete. Main parameter is its tensile strength. Following are some of the types of the glass fibers E-glass fiber, S-glass fibers, Alkali resistant glass fibers etc. [1]. Experimental study was made to study different properties of concrete by many investigators. From the experimental investigations it was proved by investigators that the workability of GFRC reduces with the increase in the fiber content as compared to the normal concrete. The 7 days and 28 days compressive strength of concrete flexural deflection, flexural strength, bond strength, shear strength increases with increase in the fiber content up to use of certain $\%$ of glass fibers [2][3]

However up till now, the use of glass fibers is mostly restricted to plain and R.C.C. It is yet not used on large scale for Prestressed Concrete. In this paper it is mainly highlighted the use of "Anti crack glass fibers" in prestressed concrete and its effect on the deflection of the structural component when horizontal load is applied to it.
The actual casting of $13.0 \mathrm{~m}$ length spun pole was done at the factory and it was tested for its bent test which is mainly related to the parameters of deflection, cracking of PSC spun pole.

\section{EXPERIMENTAL INVESTIGATIONS}

The manufacturing of Prestressed Concrete tubular spun pole was being done at Beton Concrete Product Pvt. Ltd. Located at $50 \mathrm{~km}$ away from Aurangabad in Maharashtra. At the time of the experimentation, the manufacturing of $13.0 \mathrm{~m}$ length pole was in progress. The same pole was considered for the experimental investigations, just by adding anti crack glass fibers, in the proportion of 600 $\mathrm{gm} / \mathrm{cum}$ concrete, as suggested by the manufacturer of the glass fibers. The details of the materials [4] used for pole under investigation were as below

\section{Cement}

The type of the cement used was OPC, Orient Gold 53 grade having specific gravity of 2.90 and fineness of $2800 \mathrm{~cm}^{2} / \mathrm{gm}$.

\section{Fine Aggregate}

The sand used was procured from Godavari River. The sieve analysis was carried out and it was having fineness modulus as 4.10 ,specific gravity 2.75 ,other parameters observed are silt content $1.3 \%$, water absorption $1.0 \%$ and bulk density $1718 \mathrm{~kg} / \mathrm{cum}$.

3. Coarse Aggregate

Machined crushed, angular shaped aggregates of maximum size of $12.00 \mathrm{~mm}$ were used. The other properties 
were, Specific gravity 2.60, Fineness modulus 7.80, Bulk Density $1511 \mathrm{~kg} / \mathrm{cum}$ and water absorption $0.5 \%$.

\section{Admixture}

In addition to above regular ingredients, Starex Cement Additive Powder is used as admixture for achieving high early strength. The proportion used is $120 \mathrm{gm}$ per pole ( $0.05 \%$ of cement)

5. Concrete Mix

The M50 grade of high strength concrete [5] was used for casting of pole and the quantities of various ingredients per cum are as shown in Table No. 1 below.

The table 1 includes the quantities of cement, fine aggregates, and coarse aggregates in $\mathrm{kg}$., and water required in liters. These quantities were as per concrete mix design adopted for the work.

Table 1: Mix Proportion and Quantities of Various Ingredients

(Appearing on a separate page)

The proportion of the mix related to above ingredient quantities is $1: 1.29: 2.47$ with $0.4 \mathrm{w} / \mathrm{c}$ ratio. Water cement ratio 0.4 is including the wastage of the water during the process of spinning which is nearly $10 \%$. While spinning the excess water comes out and accordingly the theoretical w/c ratio considered as 0.36

6. Anti Crack Glass Fiber

Anti crack glass fibers are alkali resistant glass fibers specially developed for the reinforcement of cementatious mortars and cement concrete mix. The properties of anti crack glass fibers given by its manufacturer are as shown in table No. 2

Table 2: Properties of Highly Dispersed Anti Crack Glass Fibers

(Appearing on a separate page)

\section{IMPORTANT PARAMETERS OF POLE}

The important design parameters adopted for the design of the pole were as below:

Length of the pole $13.0 \mathrm{~m}$, Working Load $350.0 \mathrm{~kg}$, Ultimate Load $700 \mathrm{~kg}$, Top Diameter of the pole (OD) 206 $\mathrm{mm}$, Bottom Diameter of the pole (OD) $379 \mathrm{~mm}$, Thickness of the pole $50 \sim 55 \mathrm{~mm}$, Weight of the pole $1285 \mathrm{~kg}$

The details of the reinforcement used are as below

Prestressing Steel: 3 mm x 3 ply - 12 nos.

Unmentioned Steel: 4 mm x 6 No.

Spirals: $2.70 \mathrm{~mm}$ dia at $40 \mathrm{~mm}$ c/c up to $1.50 \mathrm{~m}$ from top and bottom, in remaining length $100 \mathrm{~mm} \mathrm{c} / \mathrm{c}$

Prestressing Force required for design load: $31620 \mathrm{kN}$

Total Weight of Steel in one pole: $36 \mathrm{~kg}$

\section{METHODOLOGY}

To cast PSC pole following steps were [6] followed:

1. Mixing of Various Ingredients

The mixing of various ingredients of the concrete as per concrete mix design was done in the Ready Mixed Concrete (RMC) Plant established at the factory site, as per normal procedure generally adopted.

2. Mixing of Anti Crack Glass Fibers in the Concrete [7]

The anti crack glass fibers were added in the given proportion, after thorough mixing of all the ingredients is completed to achieve uniform dispersion of the fibers in the concrete mix. The mixing period of glass fibers was kept as one minute. [8]

Anti crack glass fibers shall not be added at the initial stage, as in dry mix there is a possibility that glass fibers may stick up to sand or aggregate and the uniform dispersion may not be achieved.

3. Casting of Concrete Cubes

The cubes of the size $150 \times 150 \times 150 \mathrm{~mm}$ were cast to ascertain the compressive strength of the concrete at various stages of prestressing. The cube test results without and with anti crack glass fibers are shown in table 3

Table 3: Cube Test Results

separate page)

(Appearing on a

Rate of addition of anti crack glass fiber was comparatively low; no significant increase in the compressive strength was recorded after 24 hours. However the strength at 7 days and 14 days was seen to be increased approximately by $2.63 \%$ and $2.80 \%$ respectively.

4. Manufacturing of PSC Tubular Spun Pole

Once the mix is prepared, the casting of the pole was done by spinning process. The spin cycle time is of 20 minute and the rate of increase of speed of the spinning is, first 3 minutes@300 rpm, next 2 minutes@600 rpm, and final15 minutes@1200 rpm

5. Curing Practice

a. Steam Curing

1. Steam pressure $: 3.5$ to $5.00 \mathrm{~kg} / \mathrm{cm}^{2}$

2. Steam temperature : $65^{\circ} \mathrm{C}$ to $70^{\circ} \mathrm{C}$

3. Steam cycle time : 2 hours pre-heating +6 hours heating +2 hours pre-cooling.

b. Water curing cycle time : One day steam curing followed by 13 days water curing.

\section{TESTING OF POLE AND DISCUSSION OF THE RESULTS}

The important test to be carried out on tubular spun pole is the bent test. It is a measure of deflection after application of horizontal load in a specific fraction and the increased to the design load. The deflection is further related to the cracking pattern and its behavior.

\subsection{PROCEDURE FOR BENT TEST}

While actual erecting the pole on the site or at work place, the depth of foundation was considered as 2.15 meter[6] and the point of application of wind load (designed 
load in this case) was at a distance of $600 \mathrm{~mm}$ from the top of the pipe.

While taking the bent test the arrangement was made such that the bottom 2.15 meter portion was anchored in the ground and load was applied at distance of 600 meter from the top with the help of chain pulley arrangement. The whole set up was then connected to the digital meter through electro cell, which measures the applied load. A steel scale is provided towards the top end of the pole on which the deflection of the pole is measured for every load increment. The arrangement made for testing is shown in figure 1

Figure 1: Arrangement for Transverse Strength Test (Appearing on separate page)

Table No. 4 shows the deflection recorded at design load and further increased load beyond design load. It also indicates the recovery of the deflection when the load is removed. The results are shown for the poles without use of glass fibers.

Table 4: Recovery of Deflection after Removal of Load (Pole without Glass Fibers)

(Appearing on separate page)

Table No.5 shows the deflection recorded for each loading increment and recovery at the end after removal of load. The increment of the increase of the load is generally considered as $10 \%$ of the design load i.e. $35 \mathrm{~kg}$ in this case as the design load considered for the pole is $350 \mathrm{~kg}$.[6]

Table 5: Deflection of Spun Pole after Application of Horizantal Load

(Appearing on separate page)

Table No.6 shows the deflection recorded at design load and further increased load beyond design load. It also indicates the recovery of the deflection when the load was removed. The results were shown for the poles with use of glass fibers.

Table 6: Recovery of Deflection after Removal of Load (Pole with Glass Fibers)

(Appearing on separate page)

On application of design load no cracks shall appear on the surface of the pole. When the load is increased beyond design load, the cracks start appearing on the surface. However the cracks shall disappear or close when the increasd load is removed.This is one of the acceptance criterias of the pole under consideration. Figure 2 and 3 indicates the cracks appeared when the load is increased beyond design load.

Figure 2: Surface Cracks during the Transverse Strength Test (Pole without Glass Fibers)

(Appearing on separate page)

Figure 3: Surface Cracks during the Transverse Strength Test (Pole with Glass Fibers)

(Appearing on separate page)

Above tabulated results of deflections at various load increments verses load increments, both for poles with and without use of glass fibers can be graphically presented in the graphs shown in figure 4

Figure 4: Graph of Load and Related Deflection (Appearing on separate page)
Figure 5 indicates the graph showing variation of load verses recovery plotted for both the poles. The deflection of the pole goes on increasing with increase in the load. When the applied load is removed the deflection is reduced. However some amount of deflection is retained even after total load is removed.This is called as permanent deflection in the pole.The difference between the maximum deflection observed and permanent deflection is the recovery of the deflection. The difference between the two red points and two blue points on x-axis is the recovery of deflection for pole with and without GFR, respectively.

Figure 5: Graph showing Recovery of Deflection after Removal of Load

(Appearing on separate page)

\subsection{RESULT ANALYSIS}

\section{Concrete Cube Test Results}

From Table No. 3 it was observed that there was no significant increase in the compressive strength of the concrete using anti crack glass fibers when added at the rate of $600 \mathrm{gm} / \mathrm{cum}$

2. Deflections of the pole

From Table No. 4 it was observed that the deflection was reduced for the pole with the use anti crack glass fibers as compared to the pole without use fibers.

3. Recovery of the deflection

From Table No. 4 and 6 it was observed that $\%$ of final recovery of deflection in case of pole without use of glass fibers is up to $90 \%$. In case of pole with use of glass fibers final recovery of deflection was increased up to $95.58 \%$ (6.2\% more)

4. Appearance of Cracks and its Behavior

On application of design load no cracks were observed for pole without and with use of anti crack glass fibers.

When the load was increased beyond the design load, the hair cracks appear in both the cases. However the cracks on the surface of the pole without use of glass fibers were observed to be wider than for the pole with use of glass fibers.

After removal of load and observed after one hour period, the hair cracks were seen disappeared in both the cases. However the rate of closing of the hair cracks was comparatively fast in case of pole with use of anti crack glass fibers.

\subsection{SUITABILITY OF PRESTRESSED CONCRETE SPUN POLE AS COMPARED TO OTHER}

The prestressed concrete spun poles are found suitable as compared to poles manufactured of other material with respect to following points

1. Service life: The service life of prestressed concrete spun pole is above 50 years, for other poles it is around 15-20 years. This is because; the concrete by nature continues to increase its strength throughout the life. However the life of other material like steel, wood depends upon the environmental conditions in which it is used.

2. Minimal vibrations and deflections offer extended lamp and ballast life for lightening structure 
3. Versatility: Precast poles can be manufactured in variety of lengths, strengths and shapes.

4. Ease and speed of installation leads to faster project completion which further lower down the cost of installation.

5. Permeability: Due to process of spinning during manufacturing, the poles are highly compacted which gives almost $100 \%$ protections from permeability.

6. Through the use of standardized design and repetitive production, delivery and pricing can meet the customer's requirements.

7. Environment friendly: The majority part of the concrete comes from inert ingredients that have gone through very little transformation prior to its use in the production. For manufacturing of prestressed concrete poles, energy consumption is very low. Thus it is environment friendly from start to finish.

\section{CONCLUSIONS}

1. At every stage of increase of the load, the deflection of the pole casted using anti crack alkali resistant glass fibers is less than of the spun pole without use of glass fibers.

2. With use of anti crack glass fibers for PSC spun pole, after removal of load, the final recovery is more. This indicates that the permanent deflection of the pole with anti crack glass fibers is comparatively less.

3. With use of anti crack glass fibers the width of the surface cracks is reduced and the closing, disappearing of hair cracks appeared on the pipe surface takes less period as compared to the pole without use of anti crack fibers.

4. The load carrying capacity of the pole with use of anti crack glass fiber is increased as compared to the pole without use of glass fibers

4. There is no significant increase in the wet density of the concrete when anti crack glass fibers are added to it in less proportion.

5. The poles manufactured with other materials can be very well replaced by prestressed concrete Spun poles

\section{REFERENCES}

[1] "Technical paper on High strength glass fibers." AGY, 2006,

[2] Gugal Yuwaraj M., Deshmukh Santosh B., "Performance of Alkali resistant glass fiber reinforced concrete." Journal of Reinforced Plastics and Composites, Vol.25. No.6/2006, 61921, 623, 626-9 pp.

[3] Swami B.L.P., Asthana A.K., Masod U.,"Studies on glass fiber reinforced concrete compositesstrength and behavior". Department of Civil Engineering, Hyderabad, Department of Civil Engineering JNTU College Hyderabad, pp.601604, Challenges, opportunities and solutions in structural engineering and construction-Ghafoori (ed.) @ 2010 Taylor \& Francis group, London IBN 978-0-415-56809-8
[4] "Indian standard code of practice for prestressed concrete", IS 1343-1980

[5] "Indian Standard Code of Practice for Plain and Reinforced Cement concrete", IS 456-2000

[6] IS 13158-1991,'Indian standard prestressed concrete circular spun poles for overhead power, traction and telecommunication lines-specifications

[7] Technical specification Booklet of Beton Concrete Products Pvt. Ltd., published in the year 2009-2010

[8] Shakor Pashtiwan N and Prof. Pimpalikar S.S.," Glass Fiber Reinforced Concrete Use in Construction", Department of Civil Engineering MIT College, Pune, pp.58, AKGEC journal of Technology,vol 2.no.1,2009 
Table 1: Mix Proportion and Quantities of Various Ingredients

\begin{tabular}{|c|c|c|c|c|}
\hline Grade of concrete & Cement & Fine aggregates & $\begin{array}{c}\text { Coarse } \\
\text { aggregates }\end{array}$ & $\begin{array}{c}\text { W/C ratio/ quantity } \\
\text { of water by weight }\end{array}$ \\
\hline M 50 (Mix) & 1 & 1.29 & 2.47 & 0.40 \\
\hline $\begin{array}{c}\text { Quantity of } \\
1.0 \text { cum }\end{array}$ & $502 \mathrm{~kg}$. & $648 \mathrm{~kg}$. & $1242 \mathrm{~kg}$. & $200 \mathrm{~kg}$. or liter \\
\hline $\begin{array}{c}\text { Quantity for one } \\
\text { pole }\left(0.514 \mathrm{~m}^{3}\right)\end{array}$ & $258 \mathrm{~kg}$. & $333 \mathrm{~kg}$. & $638.20 \mathrm{~kg}$. & $103 \mathrm{~kg}$. or liter \\
\hline
\end{tabular}

Table 2: Properties of Highly Dispersed Anti Crack Glass Fibers

\begin{tabular}{|c|c|c|c|c|c|c|c|c|}
\hline $\begin{array}{c}\text { Type } \\
\text { of } \\
\text { fiber }\end{array}$ & $\begin{array}{c}\text { Density } \\
\mathrm{kg} / \mathrm{m}^{3}\end{array}$ & $\begin{array}{c}\text { Modulus of } \\
\text { Elasticity } \\
\mathrm{GPa}\end{array}$ & $\begin{array}{c}\text { Tensile } \\
\text { strength } \\
\mathrm{MPa}\end{array}$ & $\begin{array}{c}\text { Diameter of } \\
\text { filament } \\
\text { micron }\end{array}$ & $\begin{array}{c}\text { Length } \\
\mathrm{mm}\end{array}$ & $\begin{array}{c}\text { No. of } \\
\text { fibers } \\
\text { Million/kg }\end{array}$ & $\begin{array}{c}\text { Aspect } \\
\text { ratio }\end{array}$ & $\begin{array}{c}\text { Specific } \\
\text { surface } \\
\text { area } \\
\mathrm{m}^{2} / \mathrm{kg}\end{array}$ \\
\hline $\begin{array}{c}\text { Anti } \\
\text { crack }\end{array}$ & 2600 & 72 & 1700 & 14 & $12-18$ & $>200$ & $857: 1$ & 105 \\
\hline
\end{tabular}

Table 3: Cube Test Results

\begin{tabular}{|c|c|c|c|}
\hline $\begin{array}{c}\text { Stage /Age of } \\
\text { Concrete }\end{array}$ & $\begin{array}{c}\text { Compressive strength of } \\
\text { concrete } \\
\text { without use of glass fibers) } \\
\mathrm{N} / \mathrm{mm}^{2}\end{array}$ & $\begin{array}{c}\text { Compressive strength of } \\
\text { concrete } \\
\text { (with use of glass fibers) } \\
\mathrm{N} / \mathrm{mm}^{2}\end{array}$ & $\begin{array}{c}\text { \% increase in } \\
\text { compressive } \\
\text { strength }\end{array}$ \\
\hline 24 hours (1 day) & 26.5 & 27.0 & 1.88 \\
\hline 7 days & 38.0 & 39.0 & 2.63 \\
\hline 14 days & 53.5 & 55.0 & 2.80 \\
\hline
\end{tabular}

Table: 4 Recovery of Deflection after Removal of Load (Pole without Glass Fibers)

\begin{tabular}{|c|c|c|c|c|c|}
\hline Load (kg) & $\begin{array}{c}\text { Deflection } \\
(\mathrm{mm})\end{array}$ & $\begin{array}{c}\text { Deflection } \\
\text { after removal } \\
\text { of load(mm) }\end{array}$ & $\begin{array}{c}\text { Recovery } \\
(\mathrm{mm})\end{array}$ & \% Recovery & Remark \\
\hline 350 & 112 & - & - & - & No cracks seen \\
\hline $\begin{array}{c}\text { (removal of } \\
\text { load) }\end{array}$ & - & 12 & 100 & 89.29 & - \\
\hline 400 & 152 & - & - & - & 3 hair cracks seen \\
\hline $\begin{array}{c}0 \\
(\mathrm{removal} \text { of } \\
\text { load) }\end{array}$ & - & $\begin{array}{c}15 \\
\text { (after one } \\
\text { hour) }\end{array}$ & 187 & 90 & Hair cracks \\
\end{tabular}

Table: 5 Deflection of Spun Pole after Application of Horizantal Load

\begin{tabular}{|c|l|l|l|c|}
\hline $\begin{array}{c}\text { Sr.N } \\
\text { o. }\end{array}$ & $\begin{array}{c}\text { Load } \\
(\mathrm{kg} .)\end{array}$ & $\begin{array}{c}\text { Deflection of pole } \\
\text { (without use of glass fiber) }\end{array}$ & $\begin{array}{c}\text { Deflection of pole } \\
\text { (with use of glass fiber) }\end{array}$ & Remark \\
\hline 1 & 35 & 12 & 3 & - \\
\hline 2 & 70 & 18 & 8 & - \\
\hline 3 & 105 & 21 & 13.5 & - \\
\hline 4 & 140 & 37 & 24 & - \\
\hline 5 & 175 & 45 & 33.5 & - \\
\hline 6 & 210 & 56 & 45 & - \\
\hline 7 & 245 & 67 & 49 & - \\
\hline 8 & 280 & 75 & 62 & - \\
\hline 9 & 315 & 90 & 75.4 & - \\
\hline 10 & 350 & 112 & 88 & After recovery \\
\hline 11 & 0 & 12 & 2 & - \\
\hline 12 & 400 & 152 & 130 & After recovery \\
\hline 13 & 0 & 15 & - & - \\
\hline 14 & 450 & - & 180 & After recovery \\
\hline 15 & 0 & - & 8 & \\
\hline
\end{tabular}


Table 6: Recovery of Deflection after Removal of the Load (Pole Using Glass Fibers)

\begin{tabular}{|c|c|c|c|c|c|}
\hline Load $(\mathrm{kg})$ & $\begin{array}{l}\text { Deflection } \\
\quad(\mathrm{mm})\end{array}$ & $\begin{array}{l}\text { Deflection } \\
\text { after removal } \\
\text { of load } \\
(\mathrm{mm})\end{array}$ & $\begin{array}{c}\text { Recovery } \\
(\mathrm{mm})\end{array}$ & $\%$ Recovery & Remark \\
\hline 350 & 88 & - & - & - & No cracks seen \\
\hline $\begin{array}{c}0 \\
\text { (removal of load) }\end{array}$ & - & 2 & 86 & 97.73 & - \\
\hline 400 & 130 & - & - & - & 4 hair cracks seen \\
\hline 450 & 180 & - & - & - & $\begin{array}{l}5 \text { additional hair } \\
\text { cracks seen }\end{array}$ \\
\hline $\begin{array}{c}0 \\
\text { (removal of load) }\end{array}$ & - & $\begin{array}{c}8 \\
\text { (after one } \\
\text { hour) }\end{array}$ & 172 & 95.56 & $\begin{array}{c}\text { Hair cracks } \\
\text { completely closed }\end{array}$ \\
\hline
\end{tabular}

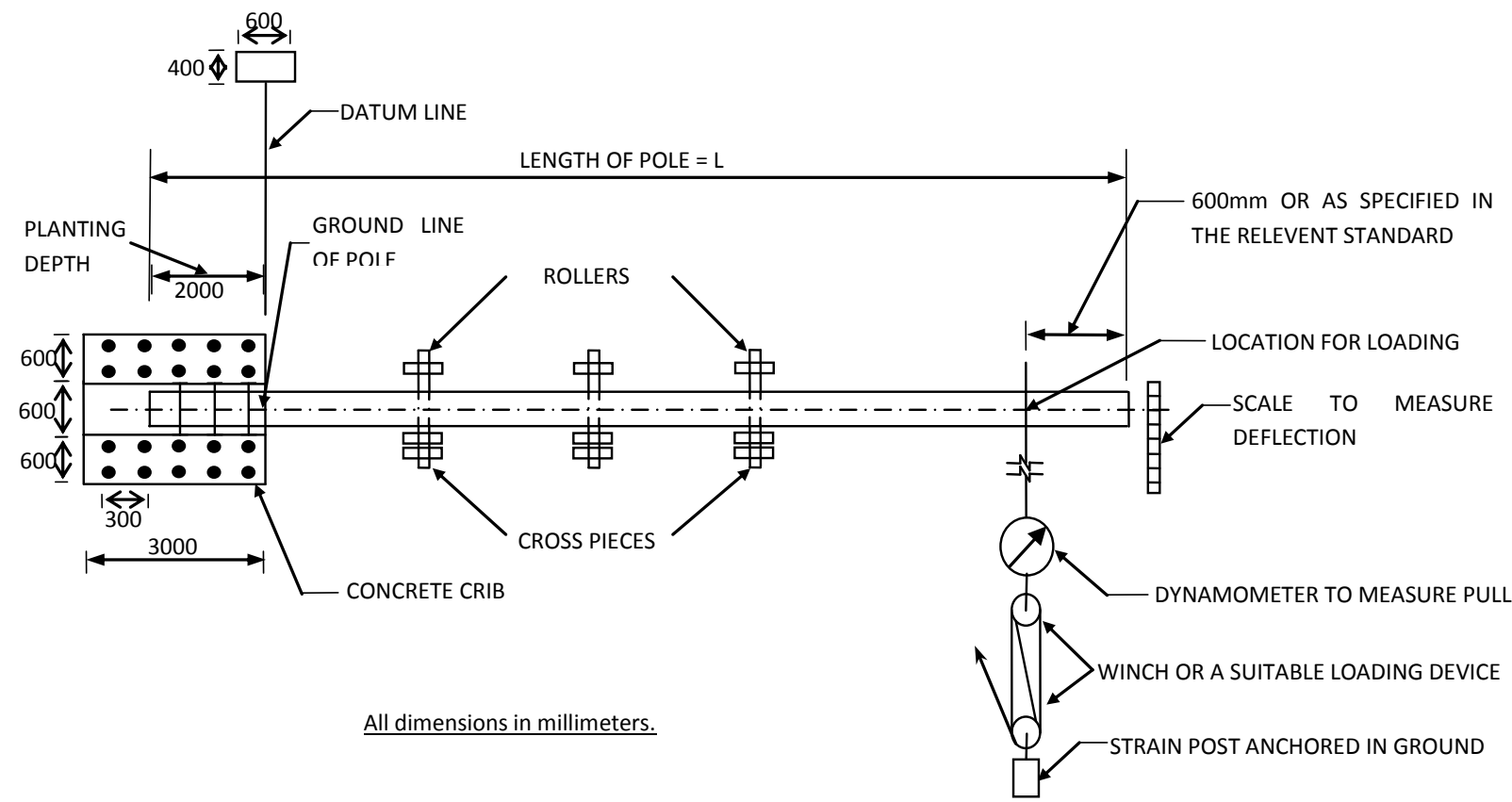

Figure 1: Arrangement for Testing

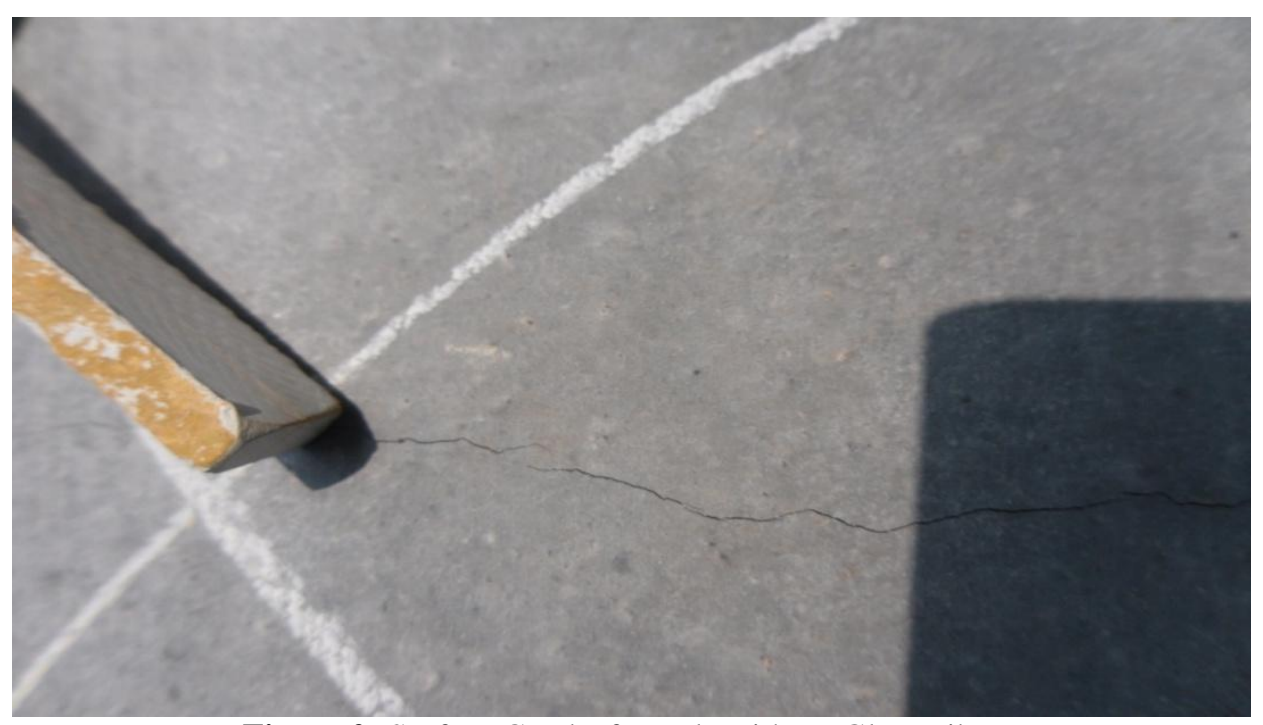

Figure 2: Surface Cracks for Pole without Glass Fibers 


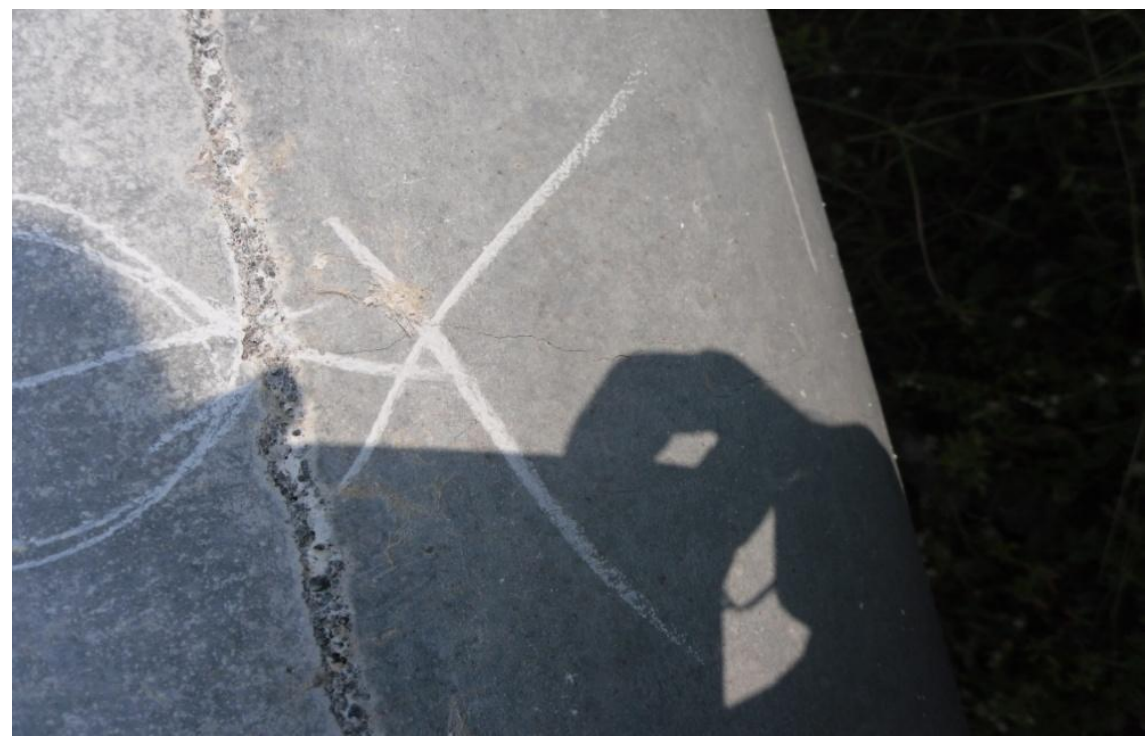

Figure 3: Surface Cracks for Pole with Glass Fibers

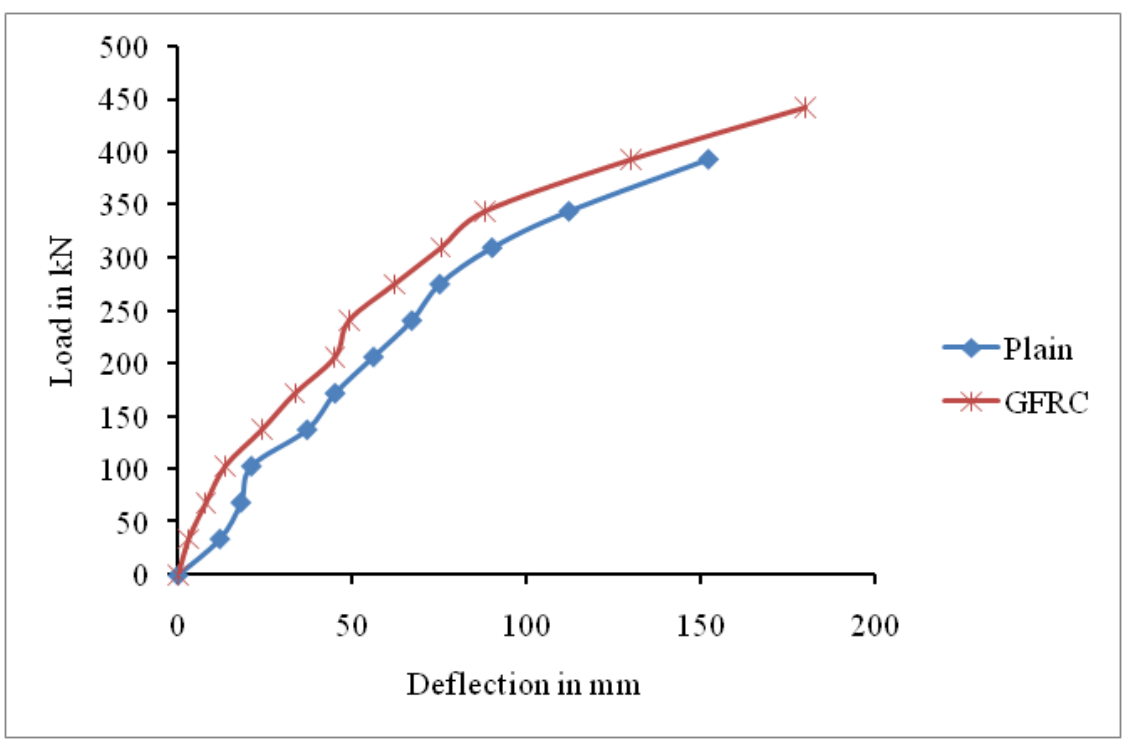

Figure 4: Graph of Load and Related Deflection

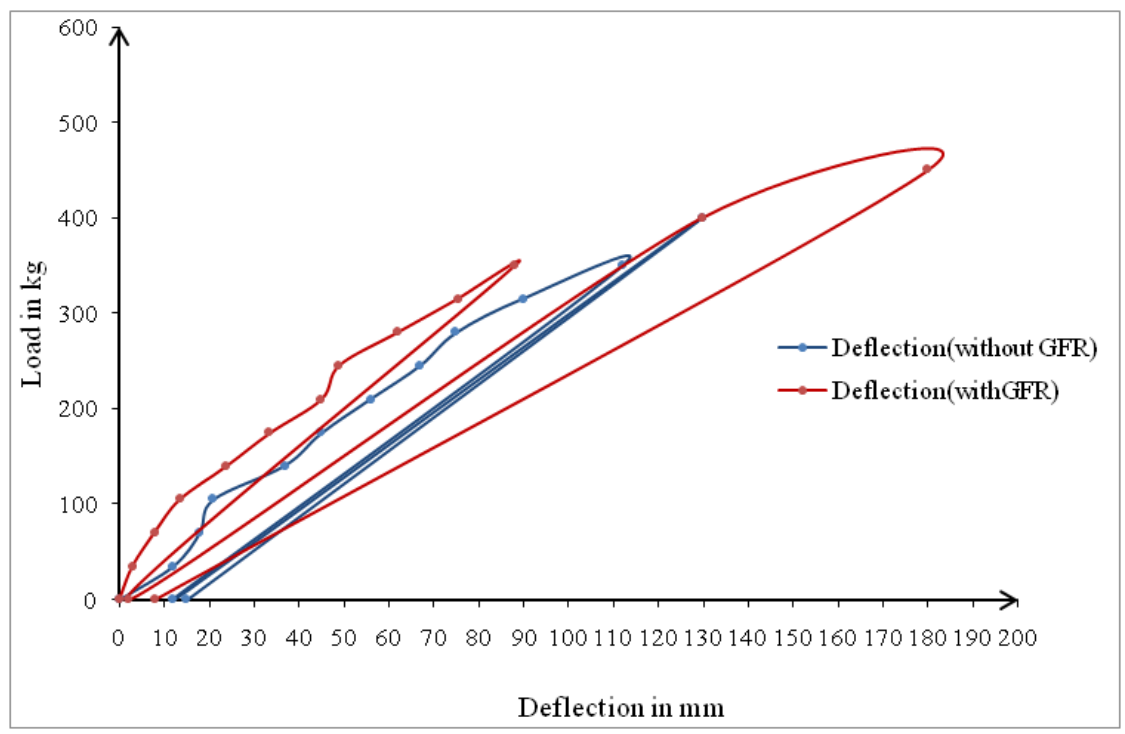

Figure 4: Graph showing Recovery of Deflection after Removal of Load 